\title{
Kink Community Education: Experiential Learning and Communities of Practice
}

\author{
Richard A. Sprott \\ Community-Academic Consortium for \\ Research on Alternative Sexualities (CARAS) (USA) \\ California State University, East Bay (USA) \\ richard.sprott@csueastbay.edu \\ Carolyn Meeker \\ Florida International University (USA) \\ Maria O'Brien \\ William Paterson University (USA)
}

\begin{abstract}
How do people learn about kink? What are the motivations to acquire knowledge and skills for doing BDSM scenes? What are the preferred ways adults want to learn? This article argues that two concepts from adult education, experiential learning and community of practice, are important frameworks for understanding how people learn about kink. As an example to illustrate these points, some findings from an educational needs assessment are presented. The results indicate gender-related differences in motivation to learn about kink and different preferences in formats for learning. Results are discussed in terms of experiential learning and community of practice.
\end{abstract}

\section{Introduction}

How do people learn about kink? What are the motivations to acquire knowledge and skills for doing BDSM scenes, and what are the preferred ways adults want to learn about kink? There is very little research into these questions, leaving a large gap in our understanding of the development of kink identities and sexualities. To address this gap in the literature, in this article we explore two concepts from adult learning, experiential learning and community of practice, in an attempt to argue for a particular theoretical approach to learning about kink and to use some results from a community educational needs assessment to illustrate how research can proceed to address these questions.

Experiential Learning

Andragogy refers to the teaching and instructional methods used in adult education. The basic theory of andragogy was developed by Malcolm Knowles in the 1950's, and the theory proposes that: (a) adults learn better when they are given explanations of why specific concepts are being taught, (b) adults learn better in response to teaching that is centered around performing tasks, (c) adults learn better when different levels of prior experience are taken into account, and (d) adult students prefer a self-directed approach that allows for discovery on their own. Andragogy also takes into account the different learning styles of the adult learners. 
Individuals who choose to learn about BDSM do so through strategies of self-directed learning (Knowles, 1975) and experiential learning (Kolb, 1984). Self-directed learning describes a process whereby an individual takes initiative to diagnose their learning needs, formulate goals for learning, and identify appropriate resources from which to learn. They also choose and implement learning strategies, and evaluate learning outcomes (Knowles, 1975). Individuals engage in a cycle of experiential learning (Kolb, 1984). First, they encounter a new experience or reinterpret an existing experience and learn by doing/feeling (concrete experience); then they reflect upon the experience (reflective observation); followed by forming new ideas or modifications to the existing ideas (abstract conceptualization); and finally apply the new ideas (active experimentation). For example, an individual might attend a BDSM workshop about rope bondage where they learn the basics of common ropes used for binding a person, how to tie knots, and where to safely place rope on a body. The attendee will consciously reflect upon their experience at the workshop and think about what they learned, possibly leading to new understandings of rope bondage or of themselves as they apply the new knowledge to future experiences. Further exploration of rope bondage might even lead to the formation of a new identity such as rigger or rope bunny.

Kolb's Experiential Learning Model (1984) suggests that individuals tend to prefer one of four learning styles: accommodator, assimilator, converger, or diverger. Individuals who prefer the accommodator style of learning tend to prefer doing things and learning through trial and error. They are attracted to new challenges, often rely on intuition rather than logic, and have a practical, experiential approach to learning. Individuals who prefer the assimilator style of learning tend to prefer using inductive reasoning, logic, and research. They often require clear explanations rather than practical opportunities, and might seem more interested in ideas and concepts, as opposed to people. Individuals who prefer the converger style of learning tend to prefer deductive reasoning, focus on specific problems, and deal with things rather than people. They are good at finding practical uses for ideas and theories. Individuals who prefer the diverger style of learning tend to prefer brainstorming and using their imagination, and are able to look at things from different perspectives. They tend to be interested in people and organizing information; prefer to watch rather than do; and gather information and use their imagination to solve problems.

\section{Informal Learning Environments and Experiential Learning}

Adults learn within formal, non-formal, and informal environments (Livingstone, 2001). Formal environments are those in which a designated teacher provides a structured curriculum related to a pre-established body of knowledge: consider, for example, courses taken within a college degree program. The learning is often long-term and there are certain programdesignated requirements in order to participate. Non-formal environments are those in which a teacher facilitates opportunities for adults to learn about self-determined interests, as found in many adult and continuing education courses and workshops. The learning is often short-term and participants determine the requirements for joining. Non-formal learning is communityrelated, flexible, learner-centered, and self-governed. Informal environments are those in which a teacher or mentor facilitates learning without adhering to a structured body of knowledge or academic criteria for completion; this includes spontaneous and incidental learning. Informal learning often occurs within communities where members are able to observe and participate in 
social activities (Paradise \& Rogoff, 2009). Schugurensky suggested that informal learning includes self-directed learning; incidental learning; and socialization, or tacit learning. Bennett (2012) expanded this conceptualization by outlining four modes of informal learning: (a) selfdirected learning, which is conscious and intentional; (b) incidental learning, which is conscious and unintentional; (c) tacit learning, which is non-conscious and unintentional; and (d) integrative, which is non-conscious and intentional.

\section{Communities of Practice}

Communities of practice are "groups of people who share a concern or a passion for something they do and learn how to do it better as they interact regularly" (Wenger-Trayner \& Wenger-Trayner, 2015). The term refers to collective learning that occurs in a shared domain of knowledge or skill, and especially in a domain that is not recognized by general, mainstream society as something that one can be an "expert" about. So, the concept explicitly includes learning about something that is stigmatized, rejected, or devalued by general society, which would clearly apply to BDSM/kink practices and skills. A community of practice is built on joint activities and sharing of information, wherein people build relationships with each other to help each other in learning or skill acquisition - even if the practice itself may be done in private or done alone.

Lave and Wenger (1991) used the term as part of their work on apprenticeships in the area of sociocultural learning theory. Grappling with apprenticeships led to significant progress in the development of sociocultural theories of learning and development, paying attention to learning outside of a formal education structure or organization. Wenger-Trayner and others have argued that "learning is a process of identity formation, which is, becoming a different person, rather than primarily the acquisition of knowledge products" (as quoted in Omidvar \& Kislov, 2014, p. 267). The sociocultural theory is a learner-centered and constructivist approach to knowledge acquisition, wherein a person's development reflects their individual process of making sense of their experience of the world, which impacts their sense of self and their social identities, which in turn directs what they learn and how they learn. Education is seen as a selfdirected process, ultimately; learning comes from intrinsic motivations and not from extrinsic pressures and influences.

This framework is useful in thinking about how people develop knowledge, acquire skills, and construct identities as they learn about kink/BDSM practices. In fact, BDSM has been described as having social networks that are "private communities of practice," where members share specialized knowledge, technical knowledge, vocabulary and terms for self-identification, and complex interactional styles (Busbee, 2008). Some learn BDSM in the context of informal social/educational groups, while some learn through personal relationships like mentoring or with sexual partners. A framework that focuses on relational qualities and contexts, especially when there is no formal organization or system, is relevant to the kinds of learning and development people experience in terms of kink/BDSM. 


\section{Sex Education in Adulthood}

It should be noted that there is very little research about adult learning when it comes to sexuality topics or domains, a gap which is starting to be addressed in the past 15 years. A number of studies report on sex education for adults with developmental disabilities (e.g., Doughty, Race \& Emery, 2017). Other studies have investigated adult sex-related retail settings as places where adult sex education occurs (Herbenick \& Reece, 2009; Reece, Herbenick \& Sherwood-Puzzello, 2004). Nodulman (2016) reported how a small chain of adult sexual retail stores in the San Francisco Bay Area, Good Vibrations, educated customers, and found that a framework of "coaching" captured the different dimensions of the education that went on in this setting: a shared responsibility for learning between coach and client; respecting the agency of the client; recognition that clients have different motivations and goals for learning; and emphasis on fun and pleasure as an important part of the process of learning.

\section{A Community Educational Needs Assessment}

To help illustrate how experiential learning and community of practice are important concepts in future work investigating how people learn about kink, we present some findings from a community educational needs assessment. In 2009, CARAS (the Community-Academic Consortium for Research on Alternative Sexualities) conducted an educational needs assessment for the BDSM/kink communities, at the urging of some community members and leaders. The needs assessment was focused on three questions: How do most people get their BDSM education? What do most people want in their BDSM education? How does it compare to other kinds of adult education? The needs assessment was not driven by any theoretical concern, nor was it guided by any theory in designing the survey. However, we feel that presenting some results from the needs assessment can bring up some interesting questions for future research. Technically, a needs assessment is not a research project, as it does not attempt to build a theory, nor are the results expected to apply to a wider population. But the results might be useful for generating research projects, and can help in the development of the practice of education, especially for educators within BDSM/kink communities.

\section{Methods}

In the Fall of 2007, after a presentation about CARAS to a leather/kink community event, a person approached the first author and asked that CARAS conduct an educational needs assessment of the leather/kink community. Discussion by the staff and Board of CARAS about this possible project ensued, and it was adopted by CARAS in keeping with its central value of being a community-based research support organization.

CARAS pulled together two teams to work on the needs assessment project. The needs assessment was designed through the work of a Technical Team and the input and feedback of a Community Advisory Team. The Technical Team included Richard A. Sprott, Ph.D. (Project Leader), Robert Bienvenu, Ph.D., CIP, Robert Gifford, Ph.D., and Charles Glickman, Ph.D. The community advisory committee included (alphabetical): Laura Antoniou, Daddy Bo, JoAnn Kokindo, Jack McGeorge, Midori, Jack Rinella, Race Bannon and Travis Wilson. The teams worked on the assessment survey and the planned process for outreach and recruitment of 
community members to participate in the educational needs assessment through most of 2008. When ready, after the survey was reviewed and evaluated by the community advisory committee, the survey went live in February of 2009 and remained open until the end of July 2009.

The CENA survey included questions about community involvement ("Currently, do you have membership in a BDSM organization or social group?"; "In the past 12 months, how many BDSM educational events have you attended?"), preferences in formats for learning (group size, mentorship, type of format for presenting information such as speakers or hands-on workshops), motivations for attending educational events, and questions about costs ("Have you not attended a BDSM educational event because it was not affordable?"; "On average, how much money do you spend to attend BDSM educational events in a year (both travel and registrations, for the entire year)?").

\section{Results of the CENA Survey}

1,649 people started the survey. Some surveys were not completed or involved people who had never attended a BDSM educational event produced by a BDSM organization. This left 1,405 usable surveys for the main analysis, resulting in an attrition rate of $14.8 \%$ in lost or unusable surveys.

The demographics of the participants covered a wide range of sexual orientations and genders, but was $90.4 \%$ White in racial/ethnic makeup. On average, participants had been involved in leather/kink for 9.28 years, and $79 \%$ belonged to a BDSM organization. The needs assessment reflects a very specific portion of the leather/kink communities and does not represent all leather/kink/BDSM community members.

\section{Rating of "Important" Sources of Education about BDSM}

Table 1 presents the rating of importance of different sources of information and education concerning BDSM practices in 2009, comparing cisgender women, cisgender men, and transgender people.

Table 2 presents a one-way analysis of variance, comparing differences in the ratings of importance between the gender identity groups of cisgender women, cisgender men and transgender people. For cisgender men, magazines and DVDs were more important sources than for cisgender women, and workshops and national conferences were more important sources for cisgender women than cisgender men. Transgender people did not differ from either cisgender men or cisgender women, in this analysis, but any differences may be masked by the low number of transgender participants in the educational needs assessment survey.

\section{Motivations for Learning}

Five different motivations were identified by the participants for attending leather/BDSM/kink community educational events: (a) to have fun, (b) to enter the kink community, (c) to maintain relationships within the community, (d) to learn new skills, and (e) to 
Table 1

Ratings of Importance of Sources of BDSM Education, by Gender

\begin{tabular}{|c|c|c|c|c|}
\hline & & $n$ & Mean & $\begin{array}{l}\text { Std. } \\
\text { Deviation }\end{array}$ \\
\hline \multirow{3}{*}{ Internet sites } & Cisgender women & 389 & 3.1311 & 1.01320 \\
\hline & Cisgender men & 284 & 3.1866 & 1.10429 \\
\hline & Transgender people & 29 & 2.9655 & 1.05162 \\
\hline \multirow{3}{*}{ Workshops } & Cisgender women & 390 & 4.0769 & .85699 \\
\hline & Cisgender men & 283 & 3.7703 & .96402 \\
\hline & Transgender people & 29 & 3.8621 & 1.09297 \\
\hline \multirow[t]{3}{*}{ Books } & Cisgender women & 389 & 3.5116 & .98074 \\
\hline & Cisgender men & 282 & 3.4645 & .95475 \\
\hline & Transgender people & 29 & 3.4828 & 1.18384 \\
\hline \multirow[t]{3}{*}{ Magazines } & Cisgender women & 388 & 1.9562 & 1.07863 \\
\hline & Cisgender men & 283 & 2.3816 & 1.18319 \\
\hline & Transgender people & 29 & 2.1034 & 1.17549 \\
\hline \multirow[t]{3}{*}{ Mentoring from friend } & Cisgender women & 391 & 3.8517 & 1.15625 \\
\hline & Cisgender men & 281 & 3.9431 & 1.10694 \\
\hline & Transgender people & 29 & 3.8621 & 1.05979 \\
\hline \multirow[t]{3}{*}{ Mentoring from sexual partner } & Cisgender women & 390 & 3.4590 & 1.24694 \\
\hline & Cisgender men & 281 & 3.6406 & 1.24885 \\
\hline & Transgender people & 29 & 3.6207 & 1.17758 \\
\hline \multirow[t]{3}{*}{ National conference } & Cisgender women & 386 & 3.5699 & 1.24693 \\
\hline & Cisgender men & 279 & 3.1864 & 1.22959 \\
\hline & Transgender people & 28 & 3.7857 & .95674 \\
\hline \multirow[t]{3}{*}{ DVD "how to" } & Cisgender women & 388 & 1.9072 & 1.03761 \\
\hline & Cisgender men & 282 & 2.3440 & 1.16539 \\
\hline & Transgender people & 29 & 1.8276 & 1.22675 \\
\hline \multirow[t]{3}{*}{ DVD porn } & Cisgender women & 381 & 1.5144 & .85405 \\
\hline & Cisgender men & 277 & 1.9747 & 1.13064 \\
\hline & Transgender people & 29 & 1.5172 & .91107 \\
\hline
\end{tabular}

Mean $=$ rating score means, where $1=$ not important at all, $5=$ most important

look for personal and play relationships. Participants were allowed to rate each motivation separately from the others on a 5-point Likert scale, with $0=$ not important at all to $4=$ most important. Table 3 presents the number of participants who rated a particular motivation to be "most important" in the list of possible motivations:

Gender differences in preferences and motivations for learning.

Of the sample, $44 \%$ identified as male, $55 \%$ identified as female, and $4 \%$ identified as transgender. Table 4 presents the differences in rating motivations for attending a BDSM educational event. 
Table 2

One Way Analysis of Variance for Sources of Information about Kink, by Gender

\begin{tabular}{|c|c|c|c|c|c|c|}
\hline & & $\begin{array}{l}\text { Sum of } \\
\text { Squares }\end{array}$ & $d f$ & $\begin{array}{l}\text { Mean } \\
\text { Square }\end{array}$ & $F$ & Sig. \\
\hline \multirow[t]{3}{*}{ Internet sites } & Between groups & 1.499 & 2 & .750 & .677 & .509 \\
\hline & Within groups & 774.388 & 699 & 1.108 & & \\
\hline & Total & 775.887 & 701 & & & \\
\hline \multirow[t]{3}{*}{ Workshops } & Between groups & 15.622 & 2 & 7.811 & 9.394 & .000 \\
\hline & Within groups & 581.211 & 699 & .831 & & \\
\hline & Total & 596.833 & 701 & & & \\
\hline \multirow[t]{3}{*}{ Books } & Between groups & .364 & 2 & .182 & .190 & .827 \\
\hline & Within groups & 668.585 & 697 & .959 & & \\
\hline & Total & 668.949 & 699 & & & \\
\hline \multirow[t]{3}{*}{ Magazines } & Between groups & 29.648 & 2 & 14.824 & 11.692 & .000 \\
\hline & Within groups & 883.729 & 697 & 1.268 & & \\
\hline & Total & 913.377 & 699 & & & \\
\hline \multirow[t]{3}{*}{ Mentoring from friend } & Between groups & 1.387 & 2 & .694 & .540 & .583 \\
\hline & Within groups & 895.934 & 698 & 1.284 & & \\
\hline & Total & 897.321 & 700 & & & \\
\hline \multirow[t]{3}{*}{ Mentoring from sexual partner } & Between groups & 5.590 & 2 & 2.795 & 1.803 & .166 \\
\hline & Within groups & 1080.369 & 697 & 1.550 & & \\
\hline & Total & 1085.959 & 699 & & & \\
\hline \multirow[t]{3}{*}{ National conference } & Between groups & 27.639 & 2 & 13.819 & 9.137 & .000 \\
\hline & Within groups & 1043.634 & 690 & 1.513 & & \\
\hline & Total & 1071.273 & 692 & & & \\
\hline \multirow[t]{3}{*}{ DVD how to } & Between groups & 33.081 & 2 & 16.541 & 13.698 & .000 \\
\hline & Within groups & 840.432 & 696 & 1.208 & & \\
\hline & Total & 873.514 & 698 & & & \\
\hline \multirow[t]{3}{*}{ DVD porn } & Between groups & 34.995 & 2 & 17.497 & 18.322 & .000 \\
\hline & Within groups & 653.235 & 684 & .955 & & \\
\hline & Total & 688.230 & 686 & & & \\
\hline
\end{tabular}

Some gender differences were found related to motivations for learning. Male-identified participants rated finding play partners and finding intimate relationships as more important to them, compared to female-identified participants. Female-identified participants favored supporting community, meeting people and to hear a particular speaker. These were classified together as maintaining community connections and relationships as a category. Transgender respondents were not different from either male or female identified respondents in two-way comparisons; this may be due to the assessment's lack of power to detect differences because of the low number of transgender-identified participants.

Gender differences were also found with respect to format preference. Male-identified people preferred learning in smaller groups, more hands-on experience, and preferred learning in private or BDSM community spaces. Female-identified people preferred learning in larger groups, more talk-based learning than hands-on, and preferred learning in public spaces. 
Table 3

Ratings of importance of motivations or reasons to attend a BDSM educational event

\begin{tabular}{|c|c|c|c|c|}
\hline & & $n$ & Mean & $\begin{array}{l}\text { Std. } \\
\text { Deviation }\end{array}$ \\
\hline \multirow{3}{*}{$\begin{array}{l}\text { To learn a new kink, new scene, new } \\
\text { technique }\end{array}$} & Cisgender women & 389 & 3.5758 & 1.09711 \\
\hline & Cisgender men & 281 & 3.5445 & 1.12709 \\
\hline & Transgender people & 28 & 3.8571 & 1.14550 \\
\hline \multirow[t]{3}{*}{ To hear a particular speaker / presenter } & Cisgender women & 389 & 3.5990 & 1.05449 \\
\hline & Cisgender men & 281 & 3.2811 & 1.06367 \\
\hline & Transgender people & 28 & 3.5000 & 1.10554 \\
\hline \multirow{3}{*}{$\begin{array}{l}\text { To meet other people interested in the } \\
\text { topic }\end{array}$} & Cisgender women & 390 & 3.6590 & 1.01359 \\
\hline & Cisgender men & 279 & 3.8172 & .98856 \\
\hline & Transgender people & 28 & 3.7143 & 1.01314 \\
\hline \multirow[t]{3}{*}{ To explore the BDSM community } & Cisgender women & 390 & 3.6308 & 1.11179 \\
\hline & Cisgender men & 279 & 3.6022 & 1.13296 \\
\hline & Transgender people & 27 & 3.3333 & 1.27098 \\
\hline \multirow[t]{3}{*}{ To meet potential BDSM play partners } & Cisgender women & 390 & 2.2487 & 1.22619 \\
\hline & Cisgender men & 280 & 2.9143 & 1.40906 \\
\hline & Transgender people & 28 & 2.5000 & 1.23228 \\
\hline \multirow{3}{*}{$\begin{array}{l}\text { To meet a potential partner or partners for } \\
\text { ongoing intimate relationships }\end{array}$} & Cisgender women & 388 & 2.0026 & 1.20185 \\
\hline & Cisgender men & 281 & 2.4591 & 1.37293 \\
\hline & Transgender people & 28 & 2.4286 & 1.19965 \\
\hline \multirow{3}{*}{$\begin{array}{l}\text { To network for professional or work- } \\
\text { related reasons }\end{array}$} & Cisgender women & 389 & 1.9743 & 1.24120 \\
\hline & Cisgender men & 281 & 1.8577 & 1.18970 \\
\hline & Transgender people & 28 & 2.2500 & 1.45615 \\
\hline \multirow{3}{*}{$\begin{array}{l}\text { To connect with old friends and } \\
\text { acquaintances }\end{array}$} & Cisgender women & 388 & 3.5490 & 1.20300 \\
\hline & Cisgender men & 280 & 3.2857 & 1.29673 \\
\hline & Transgender people & 27 & 3.5926 & 1.50024 \\
\hline \multirow{3}{*}{$\begin{array}{l}\text { To support the BDSM community } \\
\text { organization }\end{array}$} & Cisgender women & 389 & 3.7455 & 1.03770 \\
\hline & Cisgender men & 280 & 3.5286 & 1.06386 \\
\hline & Transgender people & 28 & 3.7143 & 1.18187 \\
\hline \multirow{3}{*}{$\begin{array}{l}\text { To learn how to do something that a } \\
\text { partner wants / likes to do }\end{array}$} & Cisgender women & 388 & 3.3170 & 1.20293 \\
\hline & Cisgender men & 280 & 3.3857 & 1.26483 \\
\hline & Transgender people & 28 & 2.9643 & 1.20130 \\
\hline \multirow[t]{3}{*}{ To do something fun } & Cisgender women & 390 & 4.2462 & .84289 \\
\hline & Cisgender men & 282 & 4.1312 & .93972 \\
\hline & Transgender people & 28 & 4.0000 & .98131 \\
\hline
\end{tabular}

Mean $=$ rating score averages, where $1=$ not important at all, $5=$ most important 
Table 4

One-way Analysis of Variance for Sources of Information about Kink, by gender

\begin{tabular}{|c|c|c|c|c|c|c|}
\hline & & $\begin{array}{l}\text { Sum of } \\
\text { Squares }\end{array}$ & $d f$ & $\begin{array}{l}\text { Mean } \\
\text { Square }\end{array}$ & $F$ & Sig. \\
\hline \multirow{3}{*}{$\begin{array}{l}\text { To learn a new kink, new scene, new } \\
\text { technique }\end{array}$} & Between groups & 2.491 & 2 & 1.245 & \multirow[t]{3}{*}{1.009} & \multirow[t]{3}{*}{.365} \\
\hline & Within groups & 858.135 & 695 & 1.235 & & \\
\hline & Total & 860.626 & 697 & & & \\
\hline \multirow{3}{*}{ To hear a particular speaker / presenter } & Between groups & 16.512 & 2 & 8.256 & \multirow[t]{3}{*}{7.345} & \multirow[t]{3}{*}{.001} \\
\hline & Within groups & 781.230 & 695 & 1.124 & & \\
\hline & Total & 797.742 & 697 & & & \\
\hline \multirow{3}{*}{$\begin{array}{l}\text { To meet other people interested in the } \\
\text { topic }\end{array}$} & Between groups & 4.075 & 2 & 2.038 & \multirow[t]{3}{*}{2.023} & \multirow[t]{3}{*}{.133} \\
\hline & Within groups & 699.035 & 694 & 1.007 & & \\
\hline & Total & 703.110 & 696 & & & \\
\hline \multirow{3}{*}{ To explore the BDSM community } & Between groups & 2.249 & 2 & 1.124 & \multirow{3}{*}{.886} & \multirow[t]{3}{*}{.413} \\
\hline & Within groups & 879.669 & 693 & 1.269 & & \\
\hline & Total & 881.918 & 695 & & & \\
\hline \multirow[t]{3}{*}{ To meet potential BDSM play partners } & Between groups & 72.219 & 2 & 36.109 & \multirow[t]{3}{*}{21.271} & \multirow[t]{3}{*}{.000} \\
\hline & Within groups & 1179.817 & 695 & 1.698 & & \\
\hline & Total & 1252.036 & 697 & & & \\
\hline \multirow{3}{*}{$\begin{array}{l}\text { To meet a potential partner or partners } \\
\text { for ongoing intimate relationships }\end{array}$} & Between groups & 35.436 & 2 & 17.718 & \multirow[t]{3}{*}{10.924} & \multirow[t]{3}{*}{.000} \\
\hline & Within groups & 1125.634 & 694 & 1.622 & & \\
\hline & Total & 1161.070 & 696 & & & \\
\hline \multirow{3}{*}{$\begin{array}{l}\text { To network for professional or work- } \\
\text { related reasons }\end{array}$} & Between groups & 5.052 & 2 & 2.526 & \multirow[t]{3}{*}{1.670} & \multirow[t]{3}{*}{.189} \\
\hline & Within groups & 1051.299 & 695 & 1.513 & & \\
\hline & Total & 1056.351 & 697 & & & \\
\hline \multirow{3}{*}{$\begin{array}{l}\text { To connect with old friends and } \\
\text { acquaintances }\end{array}$} & Between groups & 11.886 & 2 & 5.943 & \multirow[t]{3}{*}{3.781} & \multirow[t]{3}{*}{.023} \\
\hline & Within groups & 1087.731 & 692 & 1.572 & & \\
\hline & Total & 1099.617 & 694 & & & \\
\hline \multirow{3}{*}{$\begin{array}{l}\text { To support the BDSM community } \\
\text { organization }\end{array}$} & Between groups & 7.757 & 2 & 3.879 & \multirow[t]{3}{*}{3.490} & \multirow[t]{3}{*}{.031} \\
\hline & Within groups & 771.290 & 694 & 1.111 & & \\
\hline & Total & 779.047 & 696 & & & \\
\hline \multirow{3}{*}{$\begin{array}{l}\text { To learn how to do something that a } \\
\text { partner wants / likes to do }\end{array}$} & Between groups & 4.679 & 2 & 2.340 & \multirow[t]{3}{*}{1.551} & .213 \\
\hline & Within groups & 1045.315 & 693 & 1.508 & & \\
\hline & Total & 1049.994 & 695 & & & \\
\hline To do something fun & Between groups & 3.215 & 2 & 1.608 & 2.035 & .131 \\
\hline & Within groups & 550.515 & 697 & .790 & & \\
\hline & Total & 553.730 & 699 & & & \\
\hline
\end{tabular}

Length of BDSM involvement and preferences for learning.

We asked participants when they first attended a kink educational event as one way to measure the length of their "kink career" that was relevant to an educational needs assessment from a community perspective. Only one correlation between length of community involvement and preferences for educational format was significant: The longer the involvement, the less important was the demonstration format for kink education.

In terms of sources for information and education, there were significant negative correlations between length of involvement and use of internet sites and workshops (internet sites and workshops were more important for people early in their kink careers), and positive correlations for magazines and national events (these were more important for people who started their kink education earlier than the advent of the Internet). 


\section{Discussion}

Kink/BDSM educational workshops, meetings and mentoring involve experiential learning, are part of an education that is self-directed by learners, and can be productively understood as a community of practice. These educational concepts can illuminate why workshops and mentoring are the most important formats and sources of information and learning about kink, and why "having fun" and entering/maintaining community are important motivations for learning beyond the desire to acquire specific BDSM skills. These characteristics of kink/BDSM learning suggest that acquiring skills and knowledge about BDSM techniques and kink practices should be seen in the context of a person's sexual identity development.

If identity development is a core process in adult learning about kink/BDSM, it should not be surprising that intersectionality of social identities will affect the learning process. The results of the 2009 Community Educational Needs Assessment found gender differences in people's preferences for formats for learning about kink, and in motivations for learning about kink, but no gender differences in sources of information about kink. Men and women generally participate in lifelong learning at similar rates (Boeren, 2011) but often have different motivations and styles of learning (Leathwood, 2006; Grover \& Miller, 2014). In the CENA survey, male-identified people were motivated more by personal one-on-one reasons, while female-identified people were motivated by community reasons, and this also carried over to their preferred formats for learning, with males preferring more private, one-on-one experiential learning in BDSM spaces, whereas females preferred more public spaces, group formats and speaker/discussion activities. These results support Leathwood's (2006) assertion that lifelong learning practice is gendered and Grover and Miller's (2014) findings that women are more likely than men to participate in informal discussions and meetings. Because men and women tend to have different motivations for learning and prefer different formats, educators should examine their own assumptions about gender and learning and experiment with diverse strategies to facilitate learning.

It seems, however, that a specific gender difference in adult learning format preferences and motivations might not translate across all disciplines or domains. These gender differences also attest to how processes of identity are critically important to understand how people manage and direct their own learning as adults. However, it is clear that the gender differences found in the CENA project are not similar to the gender differences in learning styles found by previous studies of science education (Heffler, 2001; Tindall and Hamil, 2004). Is there something different about kink as a domain of knowledge and practice as opposed to other domains or disciplines, leading to differences in learning styles favored or preferred by different genders?

Length of involvement in kink community events also correlated with less preference for one type of format in learning about kink: the use of demonstrations about skills and scenes. Demonstrations involve an expert or mentor performing a particular BDSM technique while a group of novices observe; given the importance of felt experience during a BDSM scene in order to know if one is doing it well, demonstrations as a format would be limited in its effectiveness in teaching/learning a skill. In the survey, length of involvement in the kink community also reflected some generational differences in sources of information, with magazines important for 
people with more history in kink communities, and internet websites more important for people who recently got involved in kink communities.

Highlighting the processes of identity as impacting adult learning leads us to approach BDSM/kink education as a community of practice. The community of practice approach, in turn, can highlight particular research questions important to sex education, kink identity development, and social/cultural factors in sexuality communities from a positive sexuality perspective. Future research can explore questions such as: What is BDSM/kink identity? What motivates people to learn about BDSM or fetish? Do different motivations for learning interact with preferred learning styles, formats, or modes? Does a sense of stigma or levels of shame impact why, how, and where someone learns about BDSM, kink, or fetish?

\section{References}

Bennett, E. (2012). A four-part model of informal learning: Extending Schugurensky's conceptual model. Proceedings of the Adult Education Research Conference, Saratoga Springs, NY: AERC.

Boeren, E. (2011). Gender differences in formal, nonformal and informal adult learning. Studies in Continuing Education, 33(3), 333-346. doi: 10.1080/0158037X.2011.610301

Busbee, E. R. (2008). Power exchange: Interaction and identity in a BDSM community (Order No. 3317068). Available from ProQuest Dissertations \& Theses A\&I; ProQuest Dissertations \& Theses Global. (304399461)

Doughty, M., Race, L., \& Emery, P. (2017). Talking about sex: a relationship awareness group for adults with a learning disability. Learning Disability Practice, 20(5), 17-22. doi:10.7748/ldp.2017.e1836

Grover, K. S., \& Miller, M. T. (2014). Gender differences in self-directed learning practices among community members. PAACE Journal of Lifelong Learning, 23, 19-31.

Heffler, B., 2001. Individual learning style and the learning style inventory. Educational Studies, 27(3), 307-316. doi: 10.1080/ 03055690120076583

Herbenick, D., and Reece, M. (2009). In-home sex toy party facilitators as sex educators: what questions are they asked and what makes them more 'askable'? American Journal of Sexuality Education, 4(2): 178-193. https://doi.org.10. 1080/15546120903001415

Knowles, M.S. (1975). Self-Directed Learning: A guide for learners and teachers. New York, NY: Associated Press.

Kolb, D. A. 1984. Experiential learning: Experience as the source of learning and development. New Jersey: Prentice-Hall.
Lave, J., \& Wenger, E. (1991). Situated learning: Legitimate peripheral participation. Cambridge, UK: Cambridge University Press.

Leathwood, C. (2006). Gender, equity and the discourse of the independent learner in higher education.

Higher Education, 52(4): 611-33. doi: $10.1007 / \mathrm{s} 1073400524143$

Livingstone, D. W. (2001). Adults' informal learning: Definitions, findings, gaps and future research. New Approaches to Lifelong Learning (NALL) Working Paper No. 21, Centre for the Study of Education and Work, OISE/UT.

Nodulman, J. A. (2016). 'Put me in, coach, I'm ready to play': Ssexuality education for adults at Good Vibrations, Sex Education, 16:6, 649-662. doi: 10.1080/14681811.2016.1165196

Omidvar, O., \& Kislov, R. (2014). The evolution of the communities of practice approach: Toward knowledgeability in a landscape of practice-An interview with Etienne Wenger-Trayner. Journal of Management Inquiry, 23(3), 266-275. doi: $10.1177 / 1056492613505908$

Paradise, R., \& Rogoff, B. (2009). Side by side: Learning by observing and pitching in. ETHOS Journal of the Society for Psychological Anthropology, 37(1), 102-138. doi: 10.1111/j.15481352.2009.01033.x

Reece, M., Herbenick, D., and Sherwood-Puzzello, C. (2004). Sexual health promotion and adult retail stores. Journal of Sex Research, 41(2): 173-180. Https://doi.org/10.1080/00224490409552225

Tindall, T., Hamil, B. (2004). Gender disparity in science education: The causes, consequences and solutions. Education, 125 (2), 282-295.

Wenger-Trayner, E., \& Wenger-Trayner, B. (2014). Learning in landscapes of practice: A framework. In E. Wenger, M. Fenton-O'Creevy, S. Hutchinson, \& C. Kubiak (Eds.), Learning in landscapes of practice. New York, NY: Routledge. 